\title{
Diet of Phylloicus (Trichoptera: Calamoceratidae) caddisfly larvae in forest streams of western Pará, central Brazilian Amazonia
}

\author{
Dieta de larvas de Phylloicus (Trichoptera: Calamoceratidae) em riachos florestais do \\ Oeste do Pará, Amazônia central brasileira
}

Diego Ramos Pimentel ${ }^{1 *}$ (D), Sheyla Regina Marques Couceiro ${ }^{2}$ (D) and

Ana Karina Moreyra Salcedo ${ }^{3}$

\begin{abstract}
${ }^{1}$ Laboratório de Ecologia e Taxonomia de Invertebrados Aquáticos, Universidade Federal do Oeste do Pará - UFOPA, Campus Tapajós, Rua Vera Paz, s/n, bloco 11, sala 03, Bairro Salé, CEP 68035-110, Santarém, PA, Brasil

${ }^{2}$ Laboratório de Ecologia e Taxonomia de Invertebrados Aquáticos, Instituto de Ciências e Tecnologia das Águas, Universidade Federal do Oeste do Pará - UFOPA, Campus Tapajós, Rua Vera Paz, s/n, bloco 11, sala 03, Bairro Salé, CEP 68035-110, Santarém, PA, Brasil

${ }^{3}$ Departamento de Engenharia Ambiental, Centro de Ciências Naturais e Tecnologia, Universidade do Estado do Pará - UEPA, Campus Altamira, Av. Bom Jesus, s/n, Bairro Mutirão, CEP 68377-078, Altamira, PA, Brasil

*e-mail: diegorp82@yahoo.com.br
\end{abstract}

Cite as: Pimentel, D.R., Couceiro, S.R.M. and Salcedo, A.K.M. Diet of Phylloicus (Trichoptera: Calamoceratidae) caddisfly larvae in forest streams of western Pará, central Brazilian Amazonia. Acta Limnologica Brasiliensia, 2020, vol. 32, e13.

Abstract: Aim: The aquatic larvae of the Phylloicus (Trichoptera: Calamoceratidae) caddisflies are typical shredders. However, the trophic classification of Phylloicus has been based on the morphology and behaviour of the larvae. The aim of this study was to investigate the diet of caddisfly larvae Phylloicus in streams. Methods: In order to provide a more reliable classification of Phylloicus diet, we analyzed the stomach contents of 185 larvae collected, sampled with D-frame entomological net from 18 streams located in the tropical forests of western Pará, Brazil. We compared the stomach contents between the larval stages, seasons (dry and rainy), and substrates (i.e., sand, leaf litter, roots, clay and mixed substrates). Results: We identified the stomach contents as fine particulate organic matter (FPOM), coarse particulate organic matter (CPOM) and plant tissue. The diet of the Phylloicus larvae was composed basically of FPOM, independent of the larval stage $(90,4 \%)$, was a higher consumption of FPOM in the dry season and there were no significant differences in food resource between substrates. Conclusions: These findings indicate that the classification of Phylloicus as a shredder may in fact be based on the processing of leaves for the building of larval cases, rather than the diet, which is in fact detritivorous, enjoying the availability of FPOM in the streams. The great quantity of FPOM consumed by caddisfly larvae Phylloicus highlight the importance of this food resource for macroinvertebrate communities from tropical streams. Therefore, regional studies of feeding habits are needed for accurate classification trophic of Phylloicus.

Keywords: aquatic insects; tropical streams; trophic ecology; substrates.

Resumo: Objetivo: Phylloicus (Trichoptera: Calamoceratidae) é um gênero de inseto aquático cujas larvas são consideradas fragmentadoras típicas. Porém, a classificação trófica de Phylloicus tem sido baseada na morfologia e comportamento das larvas. O objetivo deste estudo foi investigar a dieta de 
larvas de Phylloicus em riachos. Métodos: Assim, para estabelecer a correta dieta alimentar de Phylloicus analisamos o conteúdo estomacal de 185 larvas coletadas, amostradas com rede entomológica $\mathrm{D}$ em 18 riachos de floresta tropical no Oeste do Pará, Brasil. Comparamos o conteúdo estomacal entre os estádios larvais, períodos sazonais (seco e chuvoso) e substratos (e.g. areia, folhiço, raiz, substrato misto). Resultados: Identificamos os conteúdos estomacais como matéria orgânica particulada fina (MOPF), matéria orgânica particulada grossa (MOPG) e tecido vegetal. Independentemente do estádio larval, a dieta de Phylloicus foi composta basicamente MOPF (90,4\%), houve maior consumo de MOPF no período seco e não houve diferenças significativas no consumo de recursos alimentares entre substratos. Conclusóes: Esses resultados indicam que a classificação de Phylloicus como fragmentador deve ser associada somente à quebra de folhas para a construção de abrigos e não a sua dieta, que é detritívora, aproveitando a disponibilidade de MOPF nos riachos. A grande quantidade de FPOM consumida por larvas de Phylloicus destaca a importância desse recurso alimentar para comunidades de macroinvertebrados de riachos tropicais. Portanto, estudos regionais de hábitos alimentares são necessários para uma classificação precisa trófica de Phylloicus.

Palavras-chave: insetos aquáticos; riachos tropicais; ecologia trófica; substratos.

\section{Introduction}

Aquatic macroinvertebrates can be classified in five basic Functional Feeding Groups (FFGs) (i.e., shredders, grazers (scrapers), collectors, filterers, and predators) based on the substrate occupied, morphological adaptations, and feeding behavior (Cummins, 2016). Shredders have mouthparts adapted for the cutting and grinding of large particles of organic material, such as leaves that fall into streams from the riparian vegetation (Cushing \& Allan, 2001; Cobo, 2005). As they feed, aquatic macroinvertebrates shredders reduce the coarse particulate organic matter (CPOM) into increasingly smaller fragments (fine particulate organic matter, FPOM), enabling the transfer of nutrients and energy to other components of the trophic web (Allan \& Castillo, 2007; Boyero et al., 2011). In turn, these insects also constitute prey for fish and other vertebrates, and are thus considered to be a key group in the ecological processes that sustain the ecosystem functioning of lower order streams (Merritt \& Cummins, 1996; Merritt et al., 2008).

The classification of FFGs provides an important research tool that has been used widely and refined progressively over the past 50 years (Cummins, 2016), permitting the evaluation of environments through the relative proportions of the different FFGs, which also provide important insights into habitat quality (e.g., Couceiro et al., 2011). Despite its analytical value, the classification of FFGs should be treated with caution when applied to the assessment of habitat quality or the trophic structure of ecosystems in tropical regions, in order to avoid biased interpretations. This is because a number of studies have shown that the diet of macroinvertebrates may vary also with life instar (Malas \& Wallace, 1977; Casas, 1996; Merritt et al., 2014), and would thus not belong to a single FFG
(Tomanova et al., 2006; Silveira-Manzotti et al., 2016; Tierno de Figueroa et al., 2019). In most cases, this would result in a considerable reduction in the number of typical shredders found in tropical streams (Buss et al., 2002; Biasi et al., 2013; Mesa et al., 2013; Gonçalves Júnior et al., 2014; Graça et al., 2015; Ferreira et al., 2015; Aguiar et al., 2018). This omnivorous behavior reflects the trophic flexibility of these taxa, with the composition of the diet being adjusted to the availability of food resource (Dudgeon, 2000; Tamaris-Turizo et al., 2020). In other words, a given taxon may be assigned to different FFGs, depending on the sampling period (Camacho et al., 2009), because in some parts of the tropics, there is stronger seasonal variation in rainfall and subsequent runoff, which transports leaf litter and debris from riparian areas to streams (Allan \& Castillo, 2007).

Given this, it may be difficult to apply the FFG approach reliably in many tropical streams, where few data are available on the functional composition of the macroinvertebrate community (Boyero et al., 2009). The approach has been used successfully for some taxa, where stable isotope analysis has recently proved to be a useful tool for determining the importance of food resources for consumers, architecture and dynamics of food networks in streams (Neres-Lima et al., 2016; Parreira de Castro et al., 2016), although not all related species (congeners in tropical and temperate areas) share the same diet (Cheshire et al., 2005; Tomanova et al., 2006; Chara-Serna et al., 2012; Ferreira et al., 2015). This has led to an expansion of research on the trophic classification of macroinvertebrates in tropical areas (e.g., Cummins et al., 2005; Tomanova et al., 2007; Príncipe et al., 2010; Uwadiae, 2010; Figueroa et al., 2011), although a regional approach must also be developed (Ferreira et al., 2015). 
In this context, we investigated the diet of caddisfly larvae Phylloicus Müller, 1880 (Trichoptera: Calamoceratidae) in some streams of central Amazonia. This genus of aquatic insects is widely distributed in the streams of South America, and its larvae are considered to be typical leaf shredders, using leaves not only for their nutrients, but also as the raw material for the construction of their cases (Wantzen \& Wagner, 2006). However, research suggest that Phylloicus larvae have shown plasticity in their dietary behavior (Ferreira et al., 2015; Tamaris-Turizo et al., 2020). Therefore, the present study considered the developmental instar of the larvae, the season (dry or rainy), and the relationship between the larvae and the substrate for the evaluation of dietary patterns contributing to the dataset on their trophic ecology and feeding behavior in tropical streams.

\section{Material and Methods}

\subsection{Study area}

The present study was conducted in 18 streams in western Pará (Brazil), streams are first and second order watercourses located within terra firme (unflooded) forest, distributed equally (9 in each case) in two areas- (i) the Alter do Chão Environmental Protection Area (EPA), and (ii) the Tapajós National Forest (Figure 1). The Alter do Chão EPA is located in the municipalities of Santarém and Belterra, and covers a total area of -16 thousand hectares, limited to the north and west by the right margin of the Tapajós River, to the south by the Aramanaí EPA and Jurutui stream, and to the west by the Mojuí dos Campos land concession (Carvalho Júnior et al., 2008; Vasconcelos et al., 2008). The Tapajós National Forest (549 thousand hectares) includes parts of the municipalities of Belterra, Aveiro, Placas, and Rurópolis. This protected area is limited to the south by the Cupari River, to the west by the Tapajós River, to the east by the BR-163 federal highway and to the north, by a latitudinal parallel that links km 50 of the BR-163 highway to the Tapajós River (Santarém-Cuiabá) (Silva, 2009; ICMBio, 2019). This area is dominated by dense tropical rainforest (Figure 1).

The region's climate is of the Ami type in the Köppen classification, with mean annual temperatures of between $25^{\circ} \mathrm{C}$ and $26{ }^{\circ} \mathrm{C}$, relative humidity of over $80 \%$ throughout the year, and mean annual precipitation of approximately $2000 \mathrm{~mm}$ (Silva et al., 2012). The dry season (monthly precipitation of less than $60 \mathrm{~mm}$ ) lasts four months.
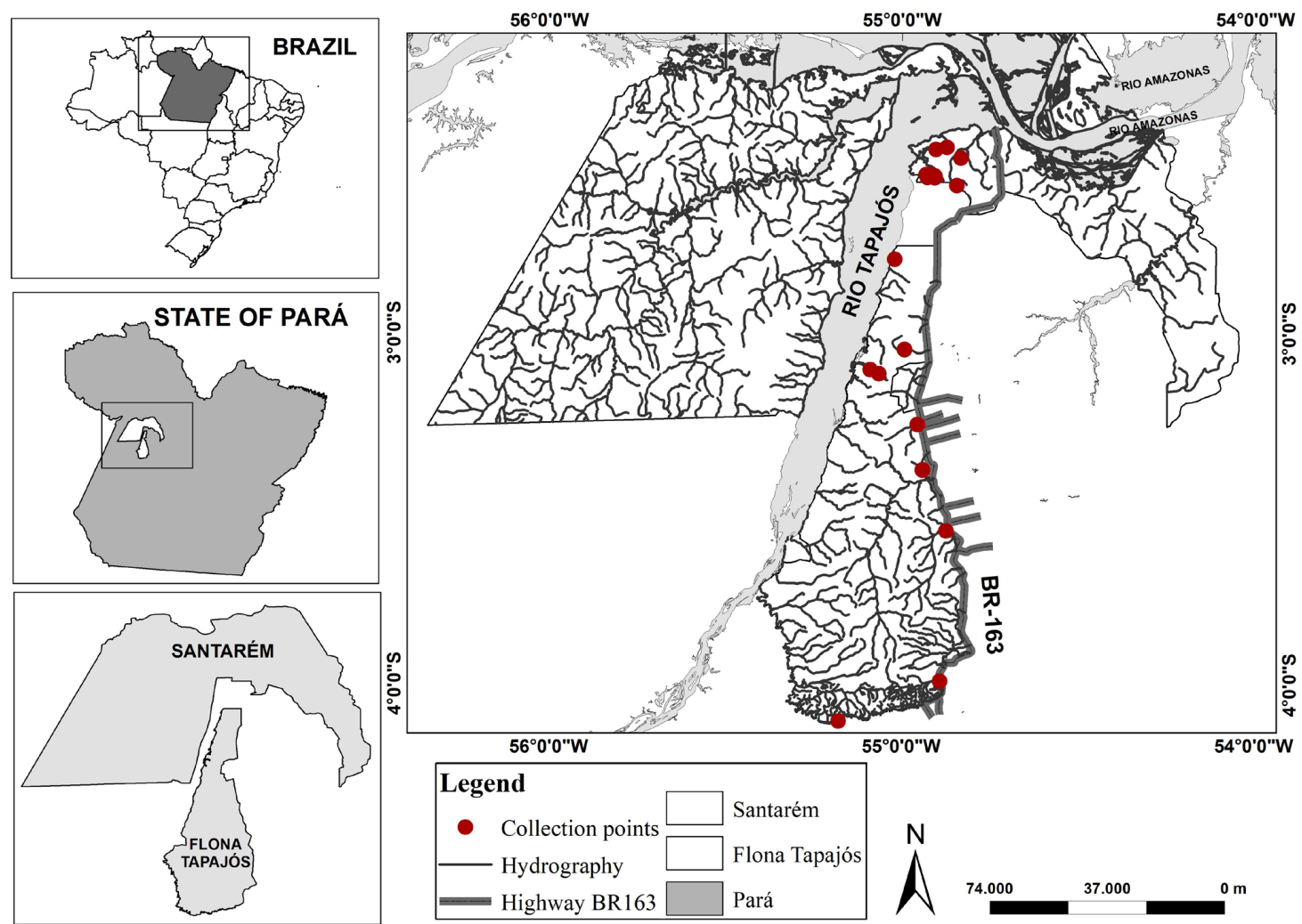

Figure 1. Location of the study streams in which the Phylloicus populations were surveyed in western Pará, Brazil. 


\subsection{Sampling}

Data were collected during the dry season (July-September) of 2013, and the subsequent rainy season, in April and May 2014. A 50-meter transect was demarcated in each stream, with five collecting points distributed at 50-m intervals. At each point, a D-frame entomological net $(30 \mathrm{~cm}$ wide, $500 \mu \mathrm{m}$ mesh) was dragged three times across the bottom over a distance of one meter, from the center of the stream to the margin, to sample different substrates, such as sand, roots, submerged leaf litter, clay and mixed substrates. All samples were preserved individually, and taken to the laboratory in plastic bags filled with $96 \%$ ethanol.

\subsection{Abiotic variables}

Abiotic variables were measured at the first, third, and fifth sampling points in each stream transect. The current speed $\left(\mathrm{m} \cdot \mathrm{s}^{-1}\right)$ was measured by the floater method, which consists of timing the displacement of a floating object over a known distance. Stream width and depth were measured using a surveyor's tape or meter ruler. The main discharge $\left(\mathrm{m}^{3} \cdot \mathrm{s}^{-1}\right)$ was obtained from the formula: discharge $=$ stream depth $\times$ stream width $\times$ current speed. Water temperature and dissolved oxygen were measured using a portable Oakton DO 110 oximeter, while the $\mathrm{pH}$ and electrical conductivity were measured buy a portable Oakton $\mathrm{pH} /$ con $10 \mathrm{~m}$ waterproof potentiometer-conductivity meter.

The opening of the canopy above each stream was estimated from photographs taken with a Canon Lens digital camera. The photographs were taken with the camera facing skywards at approximately $70 \mathrm{~cm}$ above the surface of the water. In the laboratory, the photographs were converted into black-and-white using the limiar function in Adobe Photoshop CS4. The percentage canopy opening was estimated from the number of white pixels in each photograph.

\subsection{Processing and analysis of the stomach contents}

In the laboratory, the samples were processed using a stereoscopic microscope, Petri dishes, and entomological tweezers. The Phylloicus larvae were counted for each stream and substrate, and then stored for the analysis of the stomach contents. The stomach contents were extracted from each specimen using entomological tweezers and pins, and analyzed under an optical microscope using the transparency method (Tomanova et al., 2006). The proportion of each item in the stomach contents was estimated based on the relative area occupied by the particles at 10 points chosen randomly on each slide (Zeiss Stemi 2000, magnification of $100 \mathrm{x}$ or $400 \mathrm{x}$ ). The proportion of each item observed at the 10 points was calculated and divided by 100 . Five categories of food items - modified from Tomanova et al. (2006) — were used (codes within parentheses): fine debris $<1 \mathrm{~mm}$ (FPOM), plant tissue $<1 \mathrm{~mm}$ (veg), coarse debris $>1 \mathrm{~mm}$ (CPOM), algae (alg) and invertebrates (inv).

\subsection{Data analysis}

\subsubsection{Determination of the larval instar of Phylloicus}

The width of the cephalic capsule (the distance between the two most external points) was measured to determine the larval instar (Ferreira et al., 2015). The larval instars were defined by compiling a table of width intervals for the measurements of the cephalic capsules of the Phylloicus larvae. The validity of the instars determined from the distribution of these intervals was tested using a one-way Analysis of Variance (ANOVA), with a post hoc Tukey's test. Overall, cephalic capsule measures and stomach contents were obtained for 185 Phylloicus larvae, including 95 during the dry season and 90 during the rainy season.

\subsubsection{Variation of stomach contents between instars and between substrates}

To assess difference in the composition in diet of Phylloicus between the larval instars (proportion of each item in each size instar) and difference in diet between substrates, we conducted a one-way ANOVA, followed by a post-hoc Tukey's test.

\subsubsection{Variation of abiotic variables, food resource and Phylloicus larvae}

To determine whether the abiotic variables, as well as the quantities of FPOM, CPOM and leaf matter in the stomach contents was significantly different between seasons, were applied a paired t-test.

Pearson correlation coefficients were used to evaluate the relationships between the abiotic variables and the abundance of Phylloicus larvae.

All the analyses were run in STATISTICA (v. 10.0).

\section{Results}

\subsection{Abiotic variables}

The study streams had low $\mathrm{pH}$ (4.83) and electrical conductivity $\left(17.42 \mu \mathrm{S} . \mathrm{cm}^{-1}\right)$ and moderate concentrations of dissolved oxygen $\left(5 \mathrm{mg}\right.$. $\left.\mathrm{L}^{-1}\right)$. Only 
three (stream depth, width, and current speed) of the eight abiotic variables analyzed varied significantly between seasons, and all returned higher values during the rainy season. (Table 1).

\subsection{Phylloicus and stomach contents}

The cephalic capsules of the Phylloicus larvae varied in width from 0.25 to $2.63 \mathrm{~mm}$ (mean $0.96 \mathrm{~mm} \pm 0.42$ ). The larvae were distributed in five larval instars $\left(\right.$ ANOVAF $_{(4,180)}=379.85, \mathrm{p}<0.01$ ), with 53 larvae in instar I $(0.25-0.73 \mathrm{~mm}), 86$ in instar II (0.74-1.22 mm), 39 in instar III (1.23-1.71 mm), five in instar IV (1.72-2.20 mm), and two in instar $\mathrm{V}(\geq 2.21 \mathrm{~mm})$.
The FPOM was the predominant item in the stomach contents of the Phylloicus larvae irrespective of the larval instar, but no significant variation was found $\left(\mathrm{F}_{(4,180)}=1.28, \mathrm{p}=0.28\right)$. Even if only the fraction of plant tissue is included in the analysis, no significant variation was found among the different larval instars $\left(\mathrm{F}_{(4,180)}=1.15, \mathrm{p}=0.33\right)$. The CPOM was found in the stomach contents of only four specimens ( $2 \%$ of the larvae). However, the quantity of CPOM varied significantly among the different larval instars $\left(\mathrm{F}_{(4,180)}=6.37, \mathrm{p}<0.01\right.$; Figure 2), being significantly more abundant in the final instar, albeit with reduced abundance. Based on these findings, Phylloicus was classified as

Table 1. Comparison of the abiotic variables recorded between the dry (07-09/2013) and rainy (04-05/2014) seasons.

\begin{tabular}{|c|c|c|c|c|c|}
\hline \multirow{2}{*}{ Abiotic variables } & \multicolumn{2}{|c|}{ Season } & \multicolumn{3}{|c|}{ Statistic } \\
\hline & Dry & Rainy & $\mathbf{t}$ & $p$ & df \\
\hline $\mathrm{pH}$ & $4.81 \pm 0.40$ & $4.86 \pm 0.35$ & -1.41 & 0.17 & 17 \\
\hline Water temperature $\left({ }^{\circ} \mathrm{C}\right)$ & $25.61 \pm 1.13$ & $25.74 \pm 0.97$ & -0.85 & 0.40 & 17 \\
\hline Electrical conductivity $\left(\mu \mathrm{S} . \mathrm{cm}^{-1}\right)$ & $17.66 \pm 4.81$ & $17.19 \pm 4.73$ & 1.49 & 0.15 & 17 \\
\hline Dissolved Oxygen $\left(\mathrm{mg} \cdot \mathrm{L}^{-1}\right)$ & $4.75 \pm 1.44$ & $5.26 \pm 1.06$ & 1.32 & 0.11 & 17 \\
\hline Current speed $\left({\left.\mathrm{m} . \mathrm{s}^{-1}\right)}^{-}\right.$ & $0.20 \pm 0.12$ & $0.33 \pm 0.09$ & -3.84 & $0.01^{*}$ & 17 \\
\hline Depth $(\mathrm{m})$ & $0.26 \pm 0.13$ & $1.99 \pm 1.01$ & -7.56 & $<0.01^{*}$ & 17 \\
\hline Width (m) & $1.77 \pm 1.34$ & $0.25 \pm 0.20$ & 5.16 & $<0.01^{*}$ & 17 \\
\hline Discharge $\left(\mathrm{m}^{3} \cdot \mathrm{s}^{-1}\right)$ & $0.12 \pm 0.21$ & $0.22 \pm 0.39$ & -1.22 & 0.23 & 17 \\
\hline Canopy opening (\%) & $9.77 \pm 2.57$ & $9.70 \pm 2.23$ & 0.09 & 0.92 & 17 \\
\hline
\end{tabular}

The asterisks $\left({ }^{*}\right)$ indicate significant differences $(\mathrm{p}<0.05)$ for analyses of paired $\mathrm{t}$-test; t-test $(\mathrm{t})$; $\mathrm{p}$-value $(\mathrm{p})$; degrees of freedom $(\mathrm{df})$.
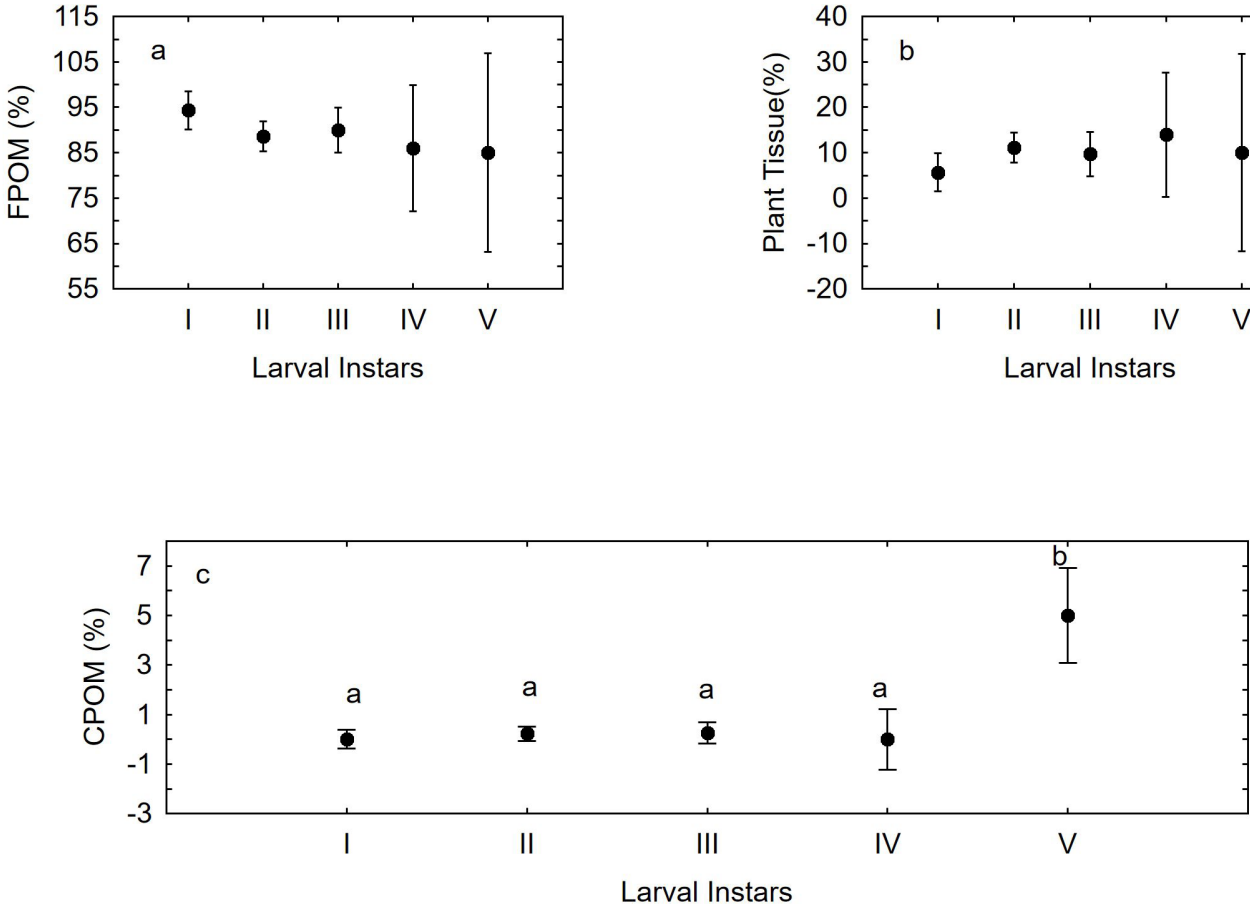

Figure 2. Variation in the proportion of fine particulate organic matter (FPOM) (a), plant tissue (b) and coarse particulate organic matter (CPOM) (c) ingested by the different larval instars of Phylloicus collected from forest streams in western Pará, Brazil. 
a detritivore, even though it is classified as a typical shredder in the current literature.

The abundance of Phylloicus was related significantly to the sites with low current speeds and lower concentrations of dissolved oxygen (Table 2), as found in the calm backwaters of the streams, where larger quantities of leaf litter tend to accumulate. Despite the greater abundance of Phylloicus in this type of environment, the ingestion of FPOM varied little among substrates $\left(\mathrm{F}_{(4,180)}=1.98, \mathrm{p}=0.09\right.$; Figure 3). The ingestion of plant tissue was also similar among the different substrates, including those with no leaf litter $\left(\mathrm{F}_{(4,180)}=2.01, \mathrm{p}=0.09\right)$. There was also little variation among substrates in the consumption of $\mathrm{CPOM}\left(\mathrm{F}_{(4,180)}=1.58, \mathrm{p}=0.18\right)$. Significantly larger quantities of FPOM were ingested during the dry season in comparison with the rainy season $(\mathrm{t}=4.95, \mathrm{p}=<0.01, \mathrm{df}=183)$, although no significant seasonal variation was observed in the ingestion of CPOM $(t=0.95, \mathrm{p}=0.34, \mathrm{df}=183)$. However, the ingestion of plant tissue, which is a component of the CPOM, was significantly higher during the rainy season $(\mathrm{t}=-5.11, \mathrm{p}<0.01$, $\mathrm{df}=183)$.

Table 2. Pearson correlations between the abiotic variables and the abundance of Phylloicus larvae in the streams in western Pará, Brazil.

\begin{tabular}{|c|c|c|}
\hline \multirow[t]{2}{*}{ Abiotic variables } & \multicolumn{2}{|c|}{ Seasons } \\
\hline & Dry & Rainy \\
\hline $\mathrm{pH}$ & $r=0.01 p=0.96$ & $r=-0.14 p=0.58$ \\
\hline Water temperature $\left({ }^{\circ} \mathrm{C}\right)$ & $r=-0.11 p=0.67$ & $r=-0.22 p=0.37$ \\
\hline Electrical conductivity $\left(\mu \mathrm{S} . \mathrm{cm}^{-1}\right)$ & $r=-0.00 p=0.99$ & $r=0.23 p=0.35$ \\
\hline Dissolved Oxygen (mg. $\left.\mathrm{L}^{-1}\right)$ & $r=0.17 p=0.49$ & $r=-0.61 p=0.01^{*}$ \\
\hline Current speed $\left(\mathrm{m} . \mathrm{s}^{-1}\right)$ & $r=-0.58 p=0.01^{*}$ & $r=0.03 p=0.90$ \\
\hline Depth (m) & $r=-0.14 p=0.57$ & $r=-0.19 p=0.44$ \\
\hline Width (m) & $r=-0.30 p=0.22$ & $r=-0.36 p=0.13$ \\
\hline Discharge $\left(\mathrm{m}^{3} . \mathrm{s}^{-1}\right)$ & $r=-0.40 p=0.09$ & $r=-0.31 p=0.21$ \\
\hline Canopy opening (\%) & $r=0.27 p=0.27$ & $r=0.31 p=0.19$ \\
\hline
\end{tabular}

The asterisks $\left(^{*}\right)$ indicate significant differences $(\mathrm{p}<0.05) ; \mathrm{r}=$ Pearson correlation coefficient.
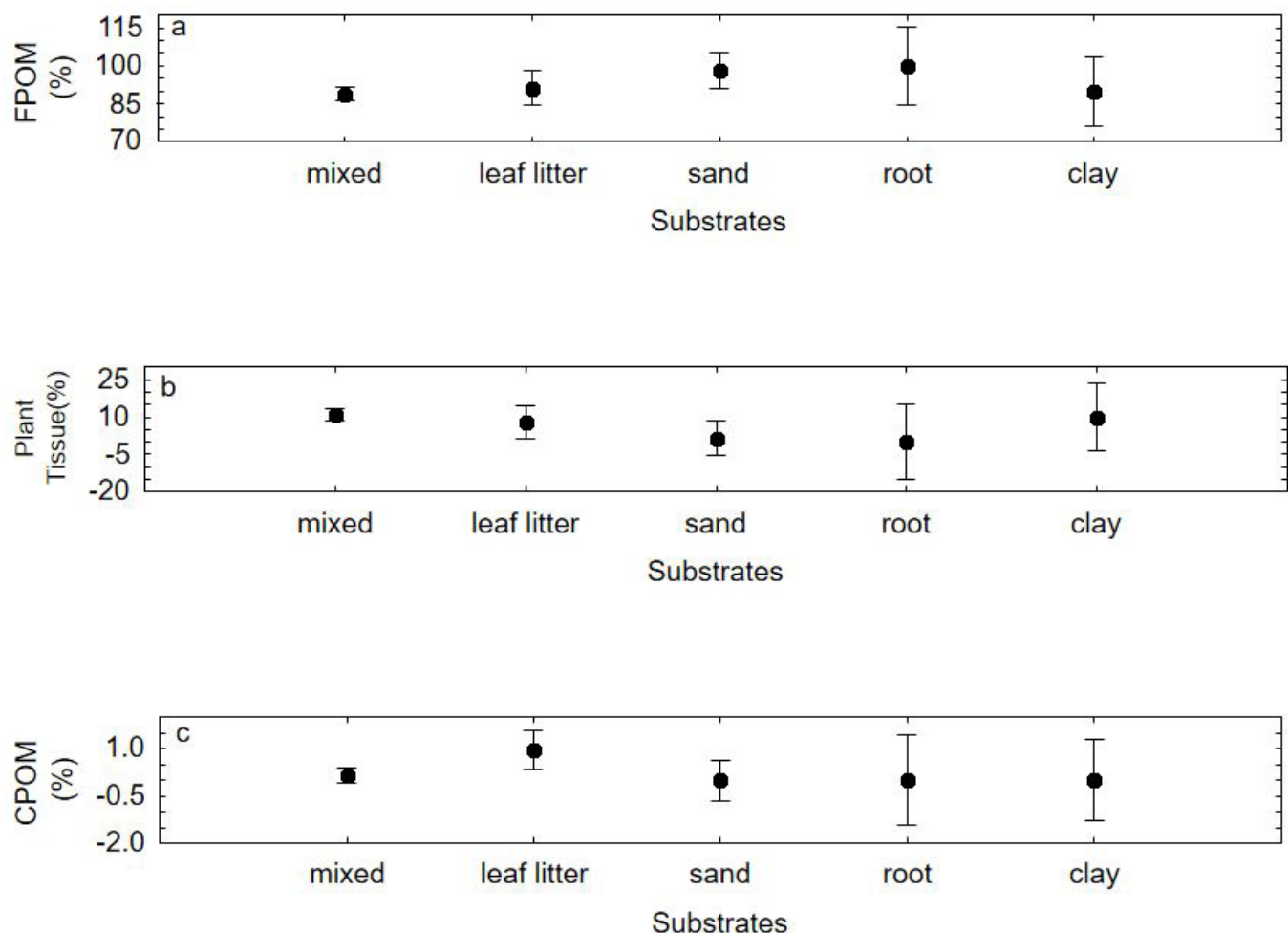

Figure 3. Variation among substrates in the proportion of fine particulate organic matter (FPOM) (a), plant tissue (b) and coarse particulate organic matter (CPOM) (c) found in the stomach contents of the Phylloicus larvae collected from forest streams in western Pará, Brazil. 


\section{Discussion}

The classification of Phylloicus as a shredder is based on the morphology of the mouthparts and the behavior of the larvae of this genus. Phylloicus larvae cut pieces of leaves with their masticatory apparatus to build their cases (Merritt \& Cummins, 1996; Merritt et al., 2008). The association of these larvae with banks of leaf litter is probably advantageous in terms of protection from predators by providing camouflage and cover, but does not necessarily imply the consumption of CPOM. In this case, the shredding behavior of these larvae would represent a behavioral (predator avoidance) strategy, rather than a feeding adaptation (Cerezer et al., 2016).

A number of studies have shown that the composition of the diet of aquatic invertebrates varies among the different larval instars (Casas, 1996; Merritt et al., 2014). In the present study, FPOM was the predominant item in the stomach contents of the Phylloicus specimens, irrespective of the larval instar, which is consistent with the findings of Ferreira et al. (2015). Ecosystems such as streams receive the input of large quantities of particulate organic matter from the erosion of the margins. The vegetation that falls into tropical streams is decomposed into fine detritus very rapidly (Mathuriau \& Chauvet, 2002; Gonçalves Júnior et al., 2012), and continuously throughout the year. In this case, the presence of FPOM (detritus) in the stomach contents of the Phylloicus larvae may be related primarily to the availability of this material in the habitat (Henriques-Oliveira et al., 2003; Chará-Serna et al., 2012). This reinforces the importance of this food resource in tropical freshwater ecosystems (Palmer et al., 1993; Motta \& Uieda., 2004; Ceneviva-Bastos \& Casatti, 2014; Silveira-Manzotti et al., 2016), related to microbial activity, which accelerates decomposition, increasing the nutritional quality of this detritus for these invertebrates (Robinson et al., 1998; Graça, 2001).

Abiotic factors, such as the type of substrate or current speed influence the distribution of aquatic insects (Fidelis et al., 2008) and the exploitation of food resource (Ferreira et al., 2015). These abiotic characteristics may thus be considered predictors of the foraging behavior of aquatic macroinvertebrates. Tomanova et al. (2006), for example, suggested that the feeding behavior of typical shredders may shift to detritivore (collector behavior) as current speeds increase, leading to a growth in the decomposition of the leaf litter, caused by the rise in the physical abrasion of the leaves, leading to their mechanical fragmentation (Abelho, 2001), which probably imposes energetic restrictions for the harvesting of $\mathrm{CPOM}$, and an increase in the availability of fine detritus.

In the present study, the abundance of Phylloicus was related significantly to areas with the lower current speeds and lower dissolved oxygen concentrations that characterize backwater environments. This provides indirect evidence that the preference for FPOM is not influenced by any increase in current speed, but rather to other factors, such as the reduced nutritional quality of the leaves (Boyero et al., 2011) and their rigidity, which may influence the exploitation of CPOM more than the abiotic variables measured in the study.

The type of substrate has also been used as a predictor of the abundance and diversity of macroinvertebrates (Minshall, 1984). Fidelis et al. (2008) confirmed that many taxa were more abundant in given types of substrate than others, a pattern related to the characteristics of the substrate and the type of feeding resource it contains. In the present study, however, the Phylloicus larvae ingested similar amounts of FPOM in practically all the substrates. In this case, the preference of the larvae for a given substrate may be more closely related to the availability of materials for building their cases, given that the large banks of leaf litter found in first order streams are appropriate for the development of Phylloicus larvae (Landeiro et al., 2010).

The FPOM was ingested in significantly larger quantities during the dry season in comparison with the rainy season, although the ingestion of CPOM did not increase during the rainy season. This may reflect the difficulties faced by the larvae for the acquisition of nutrients during a period when the environment is less stable, with the rains lead to an increase in stream depth and width, and current speeds, all of which result in the removal of food resource (Silva et al., 2009). While the ingestion of CPOM was low in both seasons, the ingestion of leaf tissue increased during the rainy season, which may be related to an increase in the input of allochthonous resources, such as fragments of plants, which are transferred to the streams by the rain (Allan \& Castillo, 2007; Uieda \& Motta, 2007; Carvalho \& Uieda, 2009; Lisboa et al., 2015). This increase in plant material implies that a greater diversity of plant species becomes available, increasing the probability that palatable items will be encountered (Lima \& Gonçalves, 2015), with their exploitation by the larvae accelerating the decomposition of the material into fine detritus, as mentioned above. 
Analyzes of stomach contents and stable isotopes in a number of tropical streams have shown that, despite the presence of dense riparian forest and the large amounts of organic material derived from the forest, the resident invertebrates satisfy most of their energetic requirements through the exploitation of autochthonous resources (Brito et al., 2006; Lau et al., 2008; Dudgeon et al., 2010; Neres-Lima et al., 2016). Given this, some authors have suggested that Neotropical shredders are more generalist than the species found in temperate zones (Wantzen \& Wagner, 2006). It is also important to remember that many aquatic insects are not restricted to a single functional feeding group, as in the case of the chironomid larvae (Nessimian \& Carvalho, 1998; Nessimian et al., 1999; Henriques-Oliveira et al., 2003) or shredders in general (Mihuc \& Mihuc, 1995; Rosi-Marshall \& Wallace, 2002; Ferreira et al., 2015). These studies have emphasized the importance of stomach contents analyzes for the reliable classification of functional feeding groups, which are classified based solely on their morphological and behavioral traits.

The results of the present study reinforce the importance of data on the stomach contents of aquatic macroinvertebrates, not only in the Amazon basin, but in all tropical aquatic ecosystems, for the reliable characterization of the role of the taxa in the trophic ecology of streams. These data will provide a much more systematic understanding of the structure and trophic dynamics of these aquatic ecosystems.

\section{Acknowledgements}

The authors are grateful to the Brazilian National Council for Science and Technology (CNPq) for providing financial support for the projects "Trophic categorization of aquatic insects using morphological traits, stomach contents, and stable isotopes" (Universal/CNPq process 477187/2012-9) and "Functional trophic groups of aquatic insects in Amazonian streams in different habitats, with emphasis on the shredders" (Bionorte/CNPq process 407698/2013-2).

\section{References}

ABELHO, M. From litterfall to breakdown in streams: a review. The Scientific World Journal, 2001, 1, 656-680. http://dx.doi.org/10.1100/tsw.2001.103. PMid:12805769.

AGUIAR, A.C.F., NERES-LIMA, V. and MOULTON, T.P. Relationships of shredders, leaf processing and organic matter along a canopy cover gradient in tropical streams. Journal of Limnology, 2018, 77, 109-120.

ALLAN, J.D. and CASTILLO, M.M. Stream ecology: structure and function of running Waters. Dordrecht: Springer, 2007. http://dx.doi.org/10.1007/978-14020-5583-6.

BIASI, C., TONIN, A.M., RESTELLO, R.M. and HEPP, L.U. The colonisation of leaf litter by Chironomidae (Diptera): The influence of chemical quality and exposure duration in a subtropical stream. Limnologica, 2013, 43(6), 427-433. http://dx.doi. org/10.1016/j.limno.2013.01.006.

BOYERO, L., PEARSON, R.G., DUDGEON, D., GRAÇA, M.A., GESSNER, M.O., ALBARIÑO, R.J., FERREIRA, V., YULE, C.M., BOULTON, A.J., ARUNACHALAM, M., CALLISTO, M., CHAUVET, E., RAMÍREZ, A., CHARÁ, J., MORETTI, M.S., GONÇALVES JÚNIOR, J.F., HELSON, J.E., CHARÁ-SERNA, A.M., ENCALADA, A.C., DAVIES, J.N., LAMOTHE, S., CORNEJO, A., LI, A.O., BURIA, L.M., VILLANUEVA, V.D., ZÚNIGA, M.C. and PRINGLE, C.M. Global distribution of a key trophic guild contrasts with common latitudinal diversity patterns. Ecology, 2011, 92(9), 1839-1848. http:// dx.doi.org/10.1890/10-2244.1. PMid:21939080.

BOYERO, L., RAMIREZ, A., DUDGEON, D. and PEARSON, R.G. Are tropical streams really different? Journal of the North American Benthological Society, 2009, 28(2), 397-403. http://dx.doi. org/10.1899/08-146.1.

BRITO, E.F., MOULTON, T.P., SOUZA, M.L. and BUNN, S. Stable isotope analysis indicates microalgae as the predominant food source of fauna in a coastal forest stream, southeast Brazil. Austral Ecology, 2006, 31(5), 623-633. http://dx.doi. org/10.1111/j.1442-9993.2006.01610.x.

BUSS, D.F., BAPTISTA, D.F., SILVEIRA, M.P., NESSIMIAN, J.L. and DORVILLÉ, L.F.M. Influence of water chemistry and environmental degradation on macroinvertebrate assemblages in a river basin in south-east Brazil. Hydrobiologia, 2002, 481(1/3), 125-136. http://dx.doi. org/10.1023/A:1021281508709.

CAMACHO, R., BOYERO, L., CORNEJO, A., IBÁÑEZ, A. and PEARSON, R.G. Local variation in shredder distribution can explain their oversight in tropical streams. Biotropica, 2009, 41(5), 625-632. http://dx.doi.org/10.1111/j.17447429.2009.00519.x.

CARVALHO JÚNIOR, E.A.R., LIMA, A.P., MAGNUSSON, W.E. and ALBERNAZ, A.L.K.M. Long-term Effect of Forest Fragmentation on the Amazonian Gekkonid Lizards, Coleodactylus amazonicus and Gonatodes humeralis. Austral Ecology, 2008, 33(6), 723-729. http://dx.doi.org/10.1111/ j.1442-9993.2008.01840.x. 
CARVALHO, E.M. and UIEDA, V.S. Diet of invertebrates sampled in leaf-bags incubated in a tropical headwater stream. Zoologia, 2009, 26(4), 694-704. http://dx.doi.org/10.1590/S198446702009000400014

CASAS, J.J. The effect of diet quality on growth and development of recently hatched larvae of Chironomus gr. plumosus. Limnetica, 1996, 12, 1-8.

CENEVIVA-BASTOS, M. and CASATTI, L. Shading effects on community composition and food web structure of a deforested pasture stream: evidences from a field experiment in Brazil. Limnologica, 2014, 46, 9-21. http://dx.doi.org/10.1016/j. limno.2013.11.005.

CEREZER, C., BIASI, C., COGO, G.B. and SANTOS, $S$. Avoid predation or take risks in basic activities? Predator-prey relationship in subtropical streams between decapods and caddisflies. Marine and Freshwater Research, 2016, 67(12), 1880. http:// dx.doi.org/10.1071/MF15278.

CHARÁ-SERNA, A.M., CHARA, J.D., ZUNIGA, M.D., PEARSON, R.G. and BOYERO, L. Diets of leaf litter-associated invertebrates in three tropical streams. International Journal of Limnology, 2012, 48(2), 139-144. http://dx.doi.org/10.1051/ limn/2012013.

CHESHIRE, K., BOYERO, L. and PEARSON, R.G. Food webs in tropical Australian streams: shredders are not scarce. Freshwater Biology, 2005, 50(5), 748-769. http://dx.doi.org/10.1111/j.13652427.2005.01355.x.

COBO, F. Maintenance of shredders in the laboratory. In: M.A.S. GRAÇA, F. BÄRLOCHER and M.O. GESSNER, eds. Methods to study litter decomposition: a practical guide. Dordrecht: Springer, 2005, pp. 291 295. http://dx.doi.org/10.1007/1-4020-3466-0_40.

COUCEIRO, S.R.M., HAMADA, N., FORSBERG, B.R. and PADOVESI-FONSECA, C. Trophic structure of macroinvertebrates in Amazonian streams impacted by anthropogenic siltation. Austral Ecology, 2011, 36, 628-637.

CUMMINS, K.W. Combining taxonomy and function in the study of stream macroinvertebrates. Journal of Limnology, 2016, 75(s1), 235-241. http://dx.doi. org/10.4081/jlimnol.2016.1373.

CUMMINS, K.W., MERRITT, R.W. and ANDRADE, P.C.N. The use of invertebrate functional groups to characterize ecosystem attributes in selected streams and rivers in southeast Brazil. Studies on Neotropical Fauna and Environment, 2005, 40(1), 69-90. http:// dx.doi.org/10.1080/01650520400025720.

CUSHING, C.E. and ALLAN, J.D. Streams: their ecology and life. San Diego: Academic Press, 2001.

DUDGEON, D. The ecology of tropical Asian rivers and streams in relation to biodiversity conservation. Annual Review of Ecology and Systematics, 2000,
31(1), 239-263. http://dx.doi.org/10.1146/annurev. ecolsys.31.1.239.

DUDGEON, D., CHEUNG, F.K.W. and MANTEL, S.K. Food web structure in small streams: do we need different models for the tropics? Journal of the North American Benthological Society, 2010, 29(2), 395-412. http://dx.doi.org/10.1899/09-058.1.

FERREIRA, W.R., LIGEIRO, R., MACEDO, D.R., HUGHES, R.M., KAUFMANN, P.R., OLIVEIRA, L. and CALLISTO, M. Is the diet of a typical shredder related to the physical habitat of headwater streams in the Brazilian Cerrado? Annales de Limnologie-Internatonal Journal of Limnology, 2015, 51(2), 115-122. http://dx.doi.org/10.1051/ limn/2015004.

FIDELIS, L., NESSIMIAN, J.L. and HAMADA, N. Distribuição espacial de insetos aquáticos em igarapés de pequena ordem na Amazônia Central. Acta Amazonica, 2008, 38(1), 127-134. http://dx.doi. org/10.1590/S0044-59672008000100014.

FIGUEROA, R., RODRÍGUEZ-BARRIOS, J., OSPINA-TÓRRES, R. and TURIZOCORREA, R. Grupos funcionales alimentarios de macroinvertebrados acuáticos en el río Gaira, Colombia. Revista de Biología Tropical, 2011, 59, 1537-1552.

GONÇALVES JÚNIOR, J.F., REZENDE, R.S., MARTINS, R.S.N.M. and GREGÓRIO, R.S. Leaf breakdown in an Atlantic Rain Forest. Austral Ecology, 2012, 37(7), 807-815. http://dx.doi.org/10.1111/ j.1442-9993.2011.02341.x.

GONÇALVES JÚNIOR, J.F., REZENDE, R.S., GREGÓRIO, R.S. and VALENTIN, G.C. Relationship between dynamics of litterfall and riparian plant species in a tropical stream. Limnologica, 2014, 44, 40-48. http://dx.doi.org/10.1016/j. limno.2013.05.010.

GRAÇA, M.A.S. The Role of Invertebrates on Leaf Litter Decomposition in Streams - a Review. International Review of Hydrobiology, 2001, 86(4-5), 383-393. http://dx.doi. org/10.1002/1522-2632(200107)86:4/5<383::AIDIROH383>3.0.CO;2-D.

GRAÇA, M.A.S., FERREIRA, W.R., FIRMIANO, K., FRANÇA, J. and CALLISTO, M. Macroinvertebrate identity, not diversity, differed across patches differing in substrate particle size and leaf litter packs in low order, tropical Atlantic forest streams. Limnetica, 2015, 34, 29-40.

HENRIQUES-OLIVEIRA, A.L., NESSIMIAN, J.L. and DORVILLÉ, J.F.M. Feeding habits of Chironomid larvae (Insecta: Diptera) from a stream in the Floresta da Tijuca, Rio de Janeiro, Brazil. Brazilian Journal of Biology $=$ Revista Brasileira de Biologia, 2003, 63(2), 269-281. http:// dx.doi.org/10.1590/S1519-69842003000200012. PMid:14509849. 
INSTITUTOCHICO MENDES DE CONSERVAÇÃO DA BIODIVERSIDADE - ICMBio . A floresta nacional do Tapajós [online]. Santarém: ICMBio, 2019 [viewed 2 Jan. 2019]. Available from: http:// www.icmbio.gov.br/flonatapajos/

LANDEIRO, V.L., HAMADA, N., GODOY, B.S. and MELO, A.S. Effects of litter patch area on macroinvertebrate assemblage structure and leaf breakdown in Central Amazonian streams. Hydrobiologia, 2010, 649(1), 355-363. http://dx.doi. org/10.1007/s10750-010-0278-8.

LAU, D.C.P., LEUNG, K.M.Y. and DUDGEON, D. Experimental dietary manipulations for determining the relative importance of allochthonous and autochthonous food resources in tropical streams. Freshwater Biology, 2008, 53, 139-147.

LIMA, L.S. and GONÇALVES, J.F.J. Heterogeneidade temporal e espacial na composiçáo química do detrito foliar. In: Livro de Resumos do II Simpósio Processos Ecológicos, Restauração e Ecovaloração em Zonas Ripárias (AquaRipária). Brasília: AquaRipária, 2015, pp. 12-15.

LISBOA, L.K., SILVA, A.L.L., SIEGLOCH, A.E., GONÇALVES JÚNIOR, J.F. and PETRUCIO, M.M. Temporal dynamics of allochthonous coarse particulate organic matter in a subtropical Atlantic rainforest Brazilian stream. Marine and Freshwater Research, 2015, 66(8), 674-680. http://dx.doi. org/10.1071/MF14068.

MALAS, D. and WALLACE, J.B. Strategies for coexistence in three species of net-spinning caddisflies (Trichoptera) in second-order southern Appalachian streams. Canadian Journal of Zoology, 1977, 55, 1829-1840.

MATHURIAU, C. and CHAUVET, E. Breakdown of leaf litter in a neotropical stream. Journal of the North American Benthological Society, 2002, 21(3), 384-396. http://dx.doi.org/10.2307/1468477.

MERRITT, R.W. and CUMMINS, K.W. An introduction to the aquatic insects of North America. Dubuque: Kendall Hunt Publishing, 1996.

MERRITT, R.W., CUMMINS, K.W. and BERG, M.B., eds. An introduction to the aquatic insects of America. Iowa: Kendall Hunt Publishing, 2008.

MERRITT, R.W., CUMMINS, K.W. and CAMPBELL, E.Y. Uma abordagem funcional para a caracterização de riachos brasileiros. In: N. HAMADA, J.L. NESSIMIAN and R.B.QUERINO, eds. Insetos aquáticos na Amazônia brasileira: taxonomia, biologia e ecologia. Manaus: INPA, 2014, pp. 69-88.

MESA, L.M., REYNAGA, M.C., CORREA, M.V. and SIROMBRA, M.G. Effects of anthropogenic impacts on benthic macroinvertebrates assemblages in subtropical mountain streams. Série Zoologia, 2013, 103(4), 342-349. http://dx.doi.org/10.1590/ S0073-47212013000400002.
MIHUC, T.B. and MIHUC, J.R. Trophic ecology of five shredders in a Rocky Mountain stream. Journal of Freshwater Ecology, 1995, 10(3), 209-216. http:// dx.doi.org/10.1080/02705060.1995.9663440.

MINSHALL, G.W. Aquatic insect-substratum relationships. In: D.M. RESH and V.H. ROSEMBERG, eds. The ecology of aquatic insects. New York: Praeger Scientific, 1984, pp. 358-400.

MOTTA, R.L. and UIEDA, V.S. Diet and trophic groups of an aquatic insect community in a tropical stream. Brazilian Journal of Biology $=$ Revista Brasileira de Biologia, 2004, 64(4), 809-817. http:// dx.doi.org/10.1590/S1519-69842004000500010. PMid:15744421.

NERES-LIMA, V., BRITO, E.F., KRSULOVIĆ, F.A.M., DETWEILER, A.M., HERSHEY, A.E. and MOULTON, T.P. High importance of autochthonous basal food source for the food web of a Brazilian tropical stream regardless of shading. International Review of Hydrobiology, 2016, 101(3-4), 132-142. http://dx.doi.org/10.1002/iroh.201601851.

NESSIMIAN, J.L. and CARVALHO, A.L. Ecologia de insetos aquáticos. Rio de Janeiro: Programa de Pósgraduaçáo em Ecologia, Universidade Federal do Rio de Janeiro, 1998.

NESSIMIAN, J.L., SANVERINO, A.M. and OLIVEIRA, A. Relações tróficas de larvas de Chironomidae (Diptera) e sua importância na rede alimentar em um brejo de dunas no Estado do Rio de Janeiro. Revista Brasileira de Entomologia, 1999, 43, 47-53.

PALMER, C., O'KEEFFE, J., PALMER, A., DUNNE, T. and RADLOFF, S. Macroinvertebrate functional feeding groups in the middle and lower reaches of the Buffalo River eastern Cape, South Africa. I. Dietary variability. Freshwater Biology, 1993, 29(3), 441453. http://dx.doi.org/10.1111/j.1365-2427.1993. tb00778.x.

PARREIRA DE CASTRO, D.M., REIS DE CARVALHO, D., POMPEU, P.S., MOREIRA, M.Z., NARDOTO, G.B. and CALLISTO, M. land use influences niche size and the assimilation of resources by benthic macroinvertebrates in tropical headwater streams. PLoS One, 2016, 11(3), e0150527. http://dx.doi.org/10.1371/journal. pone.0150527. PMid:26934113.

PRÍNCIPE, R.E., GUALDONI, C.M., OBERTO, A.M., RAFFAINI, G.B. and CORIGLIANO, M.C. Spatial-temporal patterns of functional feeding groups in mountain streams of Córdoba, Argentina. Ecología Austral, 2010, 20, 257-268.

ROBINSON, C.T., GESSNER, M.O. and WARD, J.V. Leaf breakdown and associated macroinvertebrates in alpine glacial streams. Freshwater Biology, 1998, 40(2), 215-228. http://dx.doi.org/10.1046/j.13652427.1998.00343.x. 
ROSI-MARSHALL, E.J. and WALLACE, B. Invertebrate food webs along a stream resource gradient. Freshwater Biology, 2002, 47(1), 129-141. http:// dx.doi.org/10.1046/j.1365-2427.2002.00786.x.

SILVA, E.S., MATHIAS, C.S., LIMA, M.C.F., VEIGA JUNIOR, V.F., RODRIGUES, D.P. and CLEMENT, C.R. Análise físico-química do óleo-resina e variabilidade genética de copaíba na Floresta Nacional do Tapajós. Pesquisa Agropecuária Brasileira, 2012, 47(11), 1621-1628. http://dx.doi. org/10.1590/S0100-204X2012001100009.

SILVA, F.L., PAUlETO, G.M., TALAMONI, J.L.B. and RUIZ, S.S. Categorização funcional trófica das comunidades de macroinvertebrados de dois reservatórios na região Centro-Oeste do Estado de São Paulo, Brasil. Acta Scientiarum. Biological Sciences, 2009, 31(1), 73-78. http://dx.doi.org/10.4025/ actascibiolsci.v31i1.331.

SILVA, M.L. A educação ambiental e suas contribuiçóes para a sustentabilidade da região amazônica: um estudo sobre as experiências desenvolvidas na Floresta Nacional do Tapajós. Interacçóes, 2009, 11, 122-152.

SILVEIRA-MANZOTTI, B.N., MANZOTTI, A.R., CENEVIVA-BASTOS, M. and CASATTI, L. Trophic structure of macroinvertebrates in tropical pasture streams. Acta Limnologica Brasiliensia, 2016, 28(0), 1-10. http://dx.doi.org/10.1590/S2179$975 \times 0316$.

TAMARIS-TURIZO, C.E., PINILLA-A, G.A., GUZMÁN-SOTO, C.J. and GRANADOSMARTÍNEZ, C.E. Assigning functional feeding groups to aquatic arthropods in a Neotropical mountain river. Aquatic Biology, 2020, 29, 45-57. http://dx.doi.org/10.3354/ab00724.

TIERNO DE FIGUEROA, J.M., LÓPEZRODRÍGUEZ, M.J. and VILLAR-ARGAIZ, M. Spatial and seasonal variability in the trophic role of aquatic insects: an assessment of functional feeding group applicability. Freshwater Biology, 2019, 64(5), 954-966. http://dx.doi.org/10.1111/fwb.13277.
TOMANOVA, S., GOITIA, E. and HELEŠIC, J. Trophic Levels and Functional Feeding Groups of Macroinvertebrates in Neotropical Streams. Hydrobiologia, 2006, 556(1), 251-264. http://dx.doi. org/10.1007/s10750-005-1255-5.

TOMANOVA, S., TEDESCO, P.A., CAMPERO, M., VAN DAMME, P.A., MOYA, P.A.N. and OBERDORFF, T. Longitudinal and altitudinal changes of macro-invertebrate functional feeding groups in neotropical streams: a test of the River Continuum Concept. Fundamental and Applied Limnology, 2007, 170(3), 233-241. http://dx.doi. org/10.1127/1863-9135/2007/0170-0233.

UIEDA, V.S. and MOTTA, R.L. Trophic organization and food web structure of southeastern Brazilian streams: a review. Acta Limnologica Brasiliensia, 2007, 19, 15-30.

UWADIAE, R.E. Macroinvertebrates functional feeding groups as indices of biological assessment in a tropical aquatic ecosystem: implications for ecosystem functions. New York Science Journal, 2010, 3, 6-15.

VASCONCELOS, H.L., LEITE, M.F., VILHENA, J.M.S., LIMA, A.P. and MAGNUSSON, W.E. Ant diversity in an Amazonian savanna: Relationship with vegetation structure, disturbance by fire, and dominant ants. Austral Ecology, 2008, 33(2), 221-231. http://dx.doi.org/10.1111/j.14429993.2007.01811.x.

WANTZEN, K.M. and WAGNER, R. Detritus processing by invertebrate shredders: a neotropical temperate comparison. Journal of the North American Benthological Society, 2006, 25(1), 216-232. http:// dx.doi.org/10.1899/0887-3593(2006)25[216:DPB ISA]2.0.CO;2.

Received: 03 January 2019 Accepted: 11 May 2020

Associate Editors: André Megali Amado. 